Herbert, Sir Thomas. Travels in Africa, Persia, and Asia the Great. Some Years Travels into Africa and Asia the Great, especially describing the famous Empires of Persia and Hindustan, as also divers other Kingdoms in the oriental Indies 1627-30. 1677 version, with ed., intro. and notes by John Anthony Butler.

Medieval and Renaissance Texts and Studies 427. Tempe, AZ: ACMRS, 2012. Pp. xcvii, 904. ISBN 978-0-86698-475-1 (hardcover) \$120.

As a student of empire, specifically the Ottoman Empire, I am constantly awestruck by the wealth of material available to scholars of other imperial histories, in this case the English version of the seventeenth century. Butler is the author of an intellectual biography of a better known Herbert: Edward, Baron Herbert of Chirbury (Edwin Mellen, 1990). Edward was Ambassador to France (161924 ), but was admired by his contemporaries for his work on deism, work largely untranslated into English until recently. Edward was also, as Butler notes, "a consummate egoist" who apparently remarked in his autobiography that married women, especially, "kept portraits of him hidden between their breasts" (http://www.luminarium.org/sevenlit/chirbury/chirbio.htm).

Thomas Herbert (1606-82) could "by a little imaginative genealogy" (xii) claim both Edward Herbert and William Herbert, third earl of Pembroke (1580-1630) - the founder of Pembroke College, Oxford and a patron of Shakespeare-as third cousins twice removed. William Herbert had investments in overseas adventures, notably the Bermuda Company and the Virginia Company, and it was likely he who enabled Thomas, at the age of twenty, to be included in the entourage of the embassy of Dodmore Cotton to the Shah of Persia. Herbert left on 23 March 1627 and returned 4 April 1630 (xii) to the turmoil of the Civil War, married in 1632, and went on to father ten children. He published the first edition of Travels in 1634 (xiii). Charles I appointed him to the position of Esquire of the Body in this period (how very Ottoman; much like the mendilcibașı, who carried the sultan's handkerchief).

Thomas Herbert chose to support Parliament in 1640, leading to his appointment in 1647 as Parliamentary Commissioner charged with the duty of attending Charles I (in captivity on the Isle of Wight) until his execution in 1649, where they appear to have developed a close relationship (xiv). As he stepped onto the scaffold, Charles gave Herbert his silver watch and cloak, evidence, perhaps, of a companionship of some compassion; Charles II made 
him a baron in 1660 (xvi). Herbert spent the rest of his days in antiquarian pursuits, and the periodic updating of his original travel book. He is known to have also worked on the transcription of parish records for William Dugdale's Monasticum Anglicanum (xvi), and he published the final revision of the Travels in 1677. In an extraordinary age of esoteric learning, Butler comments, Herbert stands out for prolixity and pedantry, but even an earlier editor of the work admired him as a "high-spirited and good-humoured narrator" (xviii). He might have "bristled with the prejudices and shortcomings of his time and class," but he clearly was so profoundly affected by the experience that he spent the rest of his life filling in the blanks and reworking his descriptions (xviii).

Butler's detective work in assembling this life is impressive, but even more so is the section that follows on seventeenth-century travel literature, contemporary views of it, and the importance of Herbert's description of the Persian court of the Safavids. Part 6 on Arabia and Persia runs to 440 pages in this edition, comprising more than half of the book. Butler's analysis of both the period and the significance of the material in this section of Herbert's work is instructive, touching on English intellectual life and circles of the seventeenth century, and placing the work in the emerging imperial worldview of English diplomacy and the newly founded Levant Company (1581). We learn of the Sherley affair, and an assessment of why the mission of Cotton failed in the end to establish more permanent trade relations-as much a question of rivalry with the East India Company as Persian dishonesty. The next formal contact with the Persian court did not occur until 1810, when Qajar Fath Ali Shah was on the throne (lxvii). (The new Aga Khan Museum in Toronto has an extraordinary portrait of him from the period.)

Butler's observations about Herbert's later inclusions and self-editing reveal an aging intellectual who perhaps wished to turn his memoirs into reflections on comparative cosmography and religions, including an extended section on Islam. Here, as elsewhere, the editor has restored writing left out of previous abridgements, and done a very thorough scan of both the seventeenth-century understanding of South Asia and the Middle East and present-day research, in consultation with an international array of scholars, resulting in extended and informative footnotes.

I only regret Butler's decision not to include all the illustrations, some thirty-five drawings by the traveller himself (xciii-xciv), as this edition of Herbert is likely the last we will see in paper format. Good, bad, or indifferent, 
such visual representations are as important as the text itself and of much interest these days to visual historians of these early trans-cultural ambassadors. However, a quick Google search turned up a free ebook of the 1638 original, with the illustrations included; so the choice is justifiable, and does not truly detract from Butler's extraordinary investment in the man and his time.

VIRGINIA H. AKSAN

McMaster University

\section{Hirschfeld, Heather.}

The End of Satisfaction: Drama and Repentance in the Age of Shakespeare. Ithaca: Cornell University Press, 2014. Pp. xii, 239. ISBN 978-0-8014-5274-1 (hardcover) \$55.

In The End of Satisfaction, Heather Hirschfeld interrogates the significance of satisfaction (from the Latin satisfacere, to do or make enough), elucidating how the conceptual and affective dilemma it poses in Reformation doctrine, its place in early modern structures of thought and feeling, and its imaginative representation on the English Renaissance stage inform its discursive purchase across multiple sociocultural vocabularies, including those associated with revenge, finance, and marriage. Reminding us that satisfaction signified a special calculus between transgression and atonement, the third stage of the sacrament of penance concerned with the "doing enough" or "enough done" to compensate God for human sin, Hirschfeld traces the term's history-from its prominence in religious controversy, whereby its meanings and values shifted and changed under the tremendous pressure of the Protestant Reformation, to its use on the early modern stage, whereupon, she argues, the effects of that pressure continued to resonate in secular economies of compensatory exchange: of violation and vendetta, of debt and repayment, and of erotic desire and fulfillment.

Worrying the word in the book's introduction, Hirschfeld notes how the dynamic significance of satisfaction as a principle of commensuration underwriting a range of theological transactions or exchanges has been nearly ignored by literary scholars, largely as an inherited consequence of a Protestant reorientation that focuses on the concept's appetitive dimension, almost exclusively in reference to something that humans want and/or get. The penitential 